\title{
Foraging Activity of Native Ants on Trees in Forest Fragments Colonized by the Invasive Ant Lasius neglectus
}

\author{
C. Paris ${ }^{1,2}$ and X. Espadaler ${ }^{3}$ \\ ${ }^{1}$ Department of Animal Biology, Plant Biology and Ecology, Autonomous University of Barcelona, Edifici C, \\ Campus de Bellaterra (UAB), 08193 Cerdanyola del Vallès (Bellaterra), Barcelona, Spain \\ ${ }^{2}$ Facultad de Ciencias Exactas y Naturales, Universidad de Buenos Aires, Intendente Güiraldes 2160, Lab 28, 4० Piso, \\ Ciudad Universitaria, C1428EGA Buenos Aires, Argentina \\ ${ }^{3}$ Animal Biodiversity Research Group, Ecology Unit and CREAF, Autonomous University of Barcelona, 08193 Bellaterra, Spain
}

Correspondence should be addressed to C. Paris, baikibadai@yahoo.com

Received 4 February 2012; Revised 17 April 2012; Accepted 17 April 2012

Academic Editor: James Charles Nieh

Copyright () 2012 C. Paris and X. Espadaler. This is an open access article distributed under the Creative Commons Attribution License, which permits unrestricted use, distribution, and reproduction in any medium, provided the original work is properly cited.

\begin{abstract}
Our aim was to investigate the foraging activity of native ants on tree trunks in accordance with their location in forest fragments and the presence or absence of the invasive ant Lasius neglectus. Trees were categorized as isolated, edge, or core trees according to their location in forest fragments. In invaded fragments, Lasius neglectus had the highest spatial-temporal tree visitation. Isolated trees were visited more and for a longer time by this invasive ant. Invaded fragments had low native ant activity on trees compared to fragments without L. neglectus. The few encountered native ant species showed a lower frequency of visitation and for less time in comparison with their spatial-temporal visitation in control fragments. Crematogaster scutellaris and Temnothorax lichtensteini visited all tree categories in both fragments (invaded or control) but Lasius grandis stayed for longer on isolated trees from control fragments. We conclude that in fragments invaded by Lasius neglectus, the richness of native ant foraging on trees was negatively affected. Isolated trees close to roads could act as dispersal stepping stones for Lasius neglectus.
\end{abstract}

\section{Introduction}

In ants, daily and seasonal foraging activity is mainly modulated by the interaction of abiotic and biotic variables [14]. Temperature of soil surface and relative humidity has been reported as the most relevant variables that influence ant foraging [5]. However, other abiotic variables such as sunlight, rainfall, wind intensity, atmospheric pressure, and light intensity may influence the activity of some ant species [6-9]. Foraging activity determined by physical variables is modulated by biotic variables such as interspecific competition and habitat structure [3], resource productivity [10], food type, and colony needs [11] and physiological constraints such as heat tolerance [7]. Additionally, the activity of dominant species (sensu [12]) may determine the foraging patterns of less dominant species [13]. In this regard, invasive ant species become dominant because of their aggressive behavior and the major abundance that their unicolonial social structure and polygyny (many queens per colony) allow them to achieve in a short time. In consequence, invasive ants monopolize food sources, mainly honeydewproducing insects, negatively affect native arthropods and even small vertebrates, and disrupt and develop mutualisms in native communities [14]. In short, ant-aphid interactions may have strong and pervasive effects extending across multiple trophic levels [15].

The invasive ant Lasius neglectus [16] has been proposed by Tsutsui and Suarez [17] as a candidate to become a similar problem to the Argentine ant Linepithema humile. Like other invasive ant species, L. neglectus relies on honeydew for its main food source and, but for a single instance in a grassland without trees in Tiflis [18], known food sources come exclusively from insect prey and honeydewproducing insects on trees [19]. Thus, here we limit our observations to that particular habitat: trees. L. neglectus modifies the arthropod community [20] and does not build elaborate nests. Instead, L. neglectus usually nests under flat stones [21], in the topsoil under leaf litter and even 
in trash piles (authors pers obs). In human habitats, $L$. neglectus tends to nest inside electrical devices [22]. In Spain, the distribution of Lasius neglectus comprises 20 localities. Depending on the locality, its distribution may comprise an area of several hectares where no other ant species are found or there are only a few trees that are eventually shared with other ant species (http://www.creaf.uab.es/xeg/Lasius/ Ingles/distribution.htm, last update December 2011). Up to now, this invasive ant species has never been recorded in natural sites in Spain. However, in 2007 several individuals were found foraging in a natural reserve at Argelèssur-Mer, France (http://www.creaf.uab.es/xeg/Lasius/Ingles/ argelessurmer.htm). This highlights the ability of L. neglectus to establish in natural areas.

The distribution of invasive ant species is usually shown by placing dots on a map or by painting an entire area [23]. However, a closeup view shows that not all places are equally occupied by an invasive ant species. In this regard, understanding how changes in the spatial-temporal foraging of an invasive species may help to invest control efforts only in hotly invaded areas at the right time. For two years, we have been estimating the attention and abundance of tended aphids for the invasive ant Lasius neglectus on oak trees in forest fragments in a suburban area of Catalonia, Spain. Our first impression was that not all trees were equally visited by L. neglectus and that some trees are shared or even visited only by native ants. We, therefore, wondered how the spatial-temporal foraging of native ants varies on trees in forest fragments colonized or not by the invasive ant Lasius neglectus. During the activity season, we surveyed how many and for how long native ant species foraged on trees in forest fragments colonized or not by this invasive ant. Additionally, we investigated whether the foraging activity of L. neglectus varied according to tree location (isolated, edge, or core trees) because invasive ants are mainly associated with disturbed areas as noted by Majer et al. [24] and Suarez et al. [25]. We hypothesized that the native ant species Lasius neglectus would occupy more trees located in more disturbed areas (isolated trees) and for a longer time in comparison with native species. Considering the general evidence of the effect of invasive ants on local ants [14], we expected a richer ant community in forest fragments not colonized by Lasius neglectus.

\section{Material and Methods}

2.1. Study Area. This study was performed on the campus of the Autonomous University of Barcelona $\left(41^{\circ} 30^{\prime} \mathrm{N}, 2^{\circ} 6^{\prime} \mathrm{E}\right)$, an area of 263 ha. Given its biogeographic location, relief and climatic conditions, this area is considered typical Mediterranean mixed holm oak forest. However, this original mixed forest was fragmented due to the agricultural and forest activities performed over the last two centuries. In the late sixties, when the university was built, the campus area was covered by 51.4 ha of fragmented forest [26]. At that time, in Catalonia, land use changed due to the abandonment of agricultural activities and the replacement of firewood with new sources of energy. In consequence, the forest recovered and nowadays 81 ha of the campus is fragmented into the original holm oak (Quercus ilex L.) forest, mixed forest (Pinus spp. plus Quercus spp.), and pine forest (Pinus halepensis Mill. or Pinus pinea L.). In the first two forest categories, the understory comprises Asparagus acutifolius L., Crataegus monogyna Jacq., Rubia peregrina L., Rubus ulmifolius Schott, Ruscus aculeatus L., Smilax aspera L., Viburnum tinus L. and Hedera helix L, and in more open forest areas Spartium junceum L., Juniperus communis L, and Rosmarinus officinalis L. In pine forest, the understory is scarce, with Brachypodium sylvaticum (Huds.) Beauv. and Ulex parviflorus Pourr.

The climate is Mediterranean, with a wet spring and fall and a dry winter and summer. Mean annual temperature is $16.5^{\circ} \mathrm{C}$ and mean annual rainfall is $575 \mathrm{~mm}$.

In 1997, Lasius neglectus was first recorded in a pile of rubble close to one of the University's railway stations. Nowadays, this ant occupies $15 \%$ of the campus area including forests, shrubland, gardens, and pavements (Figure 1).

2.2. Forest Fragment Traits and Surveys. We chose as large an area as possible within different fragments of mixed forest in order to survey all trees. We were constrained by the presence of dense understory mainly composed of Smilax aspera and Rubia peregrina and Rubus ulmifolius and by ravines. In April 2005, we chose three areas of $0.14 \mathrm{ha}, 0.032 \mathrm{ha}$, and $0.103 \mathrm{ha}$ occupied almost exclusively by Lasius neglectus (Figure 1). In previous years, we noticed that in invaded fragments some trees were regularly visited by native ant species. These invaded areas were separated by roads (distance range: 80 $220 \mathrm{~m}$ ). Two of the chosen areas border grassland (0.094 ha and $0.248 \mathrm{ha}$ ) where there were isolated trees. In forest sites, tree density varied between 364 and 844 trees/ha. Meanwhile on grassland, tree density was $46-53$ trees/ha.

In April 2006, we added to the study four areas of forest fragments of $0.12 \mathrm{ha}, 0.084 \mathrm{ha}, 0.04 \mathrm{ha}$, and 0.057 ha that were not occupied by Lasius neglectus. The distance between them was 220 to $2600 \mathrm{~m}$ while the distance from forest fragments invaded by Lasius neglectus ranged from 720 to $2370 \mathrm{~m}$. Tree density was $298-575$ tree/ha.

In all forest fragments, holm oaks represented 20-94\% of the surveyed trees. The other tree species included in the fragments were Quercus humilis (20-38\%), Pinus halepensis (20-60\%), and Populus alba (17-31\%).

We measured tree diameters at breast height (DBH) and differentiated trees according to their location in the forest. We considered three categories of tree: isolated trees (I) when the tree trunk was located more than $5 \mathrm{~m}$ from the forest and their crown did not contact the forest canopy, edge trees (E) when they bordered fields or roads, and finally, core trees (C) when the trunk was located $5 \mathrm{~m}$ from the forest edge and more than $60 \%$ of their crown was in contact with the crown of other closer trees. Isolated trees close to invaded forest were considered part of the invaded area.

In this study, on each sampling date, we considered a tree to be visited by a given ant species when we saw a trail on the tree trunk with workers moving downwards with their gasters full of honeydew or a few workers climbing to 

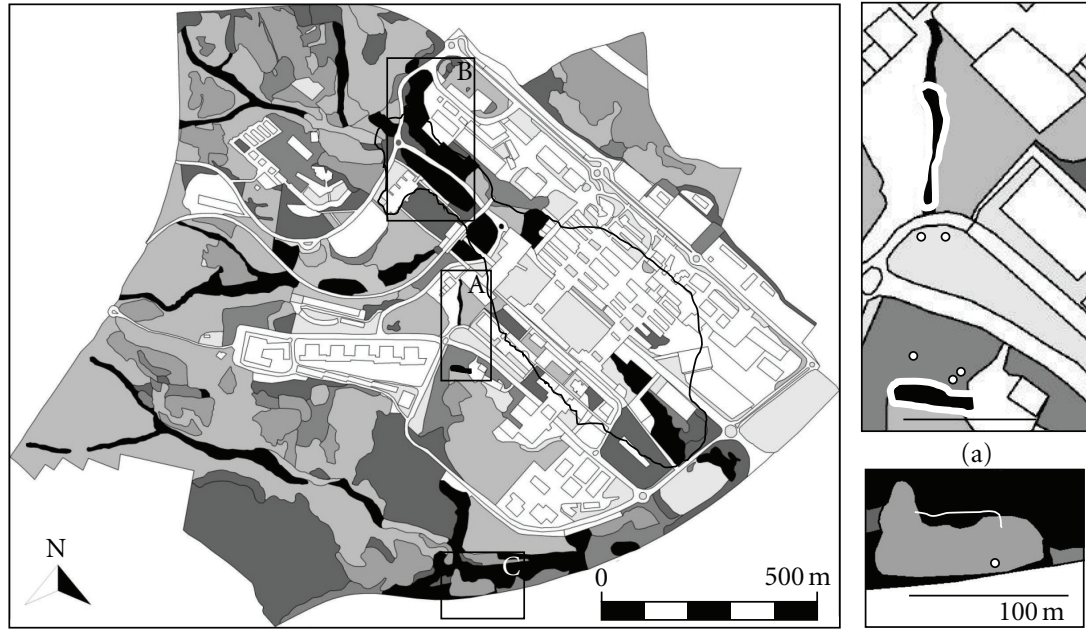

(c)

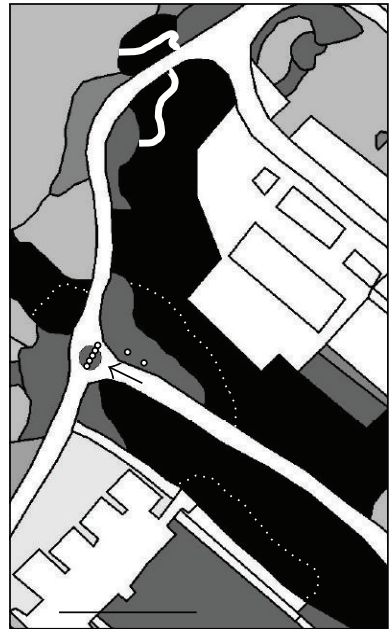

(b)
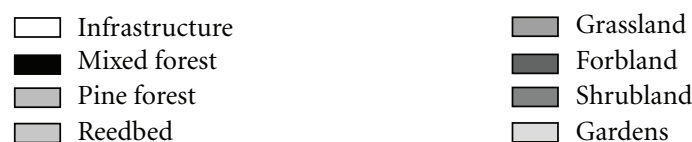

FIgURE 1: The University campus is composed by three main units. The first unit comprises all the university and transportation infrastructure like buildings, parkings, railway stations, roads, and paths. The agroforestal unit is composed by natural areas such as mixed and pine forests, shrubland, grassland and reedbed. Finally, the gardened unit included grass areas with several isolated trees and bushes. The area of the campus invaded by L. neglectus is surrounded by a black line. On the right side, areas ( $\mathrm{a}, \mathrm{b}$, and c) of the chosen invaded (dotted line) and control (continuous line) forest fragments have been enlarged. Isolated trees are shown with small white circles. The arrow, in figure (b) points a roundabout where there are five isolated trees colonized by L. neglectus.

explore the crown. Between late April and mid October, we recorded all ant species that were observed climbing all tree trunks, comprising in total 120 trees in invaded fragments and 78 trees in control fragments. We identified ant species foraging on tree trunks in the field, when possible, or we took samples for identification in the laboratory. Trees were observed between $9 \mathrm{~h}$ and $13 \mathrm{~h}$ (solar time) every $25 \pm 2$ days, (mean $\pm \mathrm{SE}$ ). Invaded fragments were surveyed in both years (2005 and 2006), while control fragments were surveyed in one year (2006).

2.3. Statistical Analysis. The size and shape of the chosen areas of fragment types (invaded or not) were compared using a $t$-test. Tree abundance of each tree category (isolated, edge and core trees) and tree diameter were compared separately using a two factor ANOVA. We considered fragment type and tree category as factors.

The analysis of foraging activity was divided into spatial tree visitation, that is, how many trees of each category were visited and temporal tree visitation, that is, for how long trees of each category were visited. We expressed foraging activity as a percentage of visited trees from each tree category and fragment type. For example, in invaded fragment \#number 2 , there were 14 core trees. In May, 11 trees were visited by the invasive ant $L$. neglectus. So, the tree visitation score was $78.5 \%$ (11/14). Prior to analysis, percentages were subjected to the arcsin transformation although raw data are presented in the text.
2.4. Foraging Activity and Richness of Native Ants. We compared ant species richness using a $t$-test considering fragment type (invaded or control) as the grouping variable.

Spatial tree visitation by native ants was compared using two-way ANOVA repeated measures including fragment type, tree category, and date of survey as fixed factors and the percentage of visited trees as the dependent variable. Temporal tree occupancy was compared using a two way ANOVA considering fragment type and tree category, as fixed factors and the number of months that a given tree was visited by native ants as the dependent variable.

When significant differences were found $(P<0.05)$ Tukey post hoc comparisons were run. All analyses were performed using Statistica 6.0 [27].

\subsection{Foraging Activity of L. neglectus and Its Effect on Native} Ants. In invaded forest fragments, spatial tree visitation of L. neglectus was analyzed using two-way repeated measures ANOVA including ant type (invasive or native), tree category (isolated, edge, core trees), and date of survey (repeated measure) as fixed factors and the percentage of visited trees as the dependent variable. In this study, we will report only those results related to the main effect of the factors or only their interaction, because at this stage we are not specifically interested in seasonal patterns. Temporal tree occupancy was compared using a two-way ANOVA considering ant type and tree category as fixed factors and the number of months 
TABle 1: Mean (SE) of forest fragment size, tree abundance and tree diameters at fragments occupied by the invasive ant Lasius neglectus (LN) or native ants (NA). Trees were categorized as: isolated trees (I), edge trees (E), or core trees (C). Total abundance of each category is after (SE). Different letters showed significant differences of post hoc comparisons of the interaction between tree category $\mathrm{x}$ fragment type (Tukey, $P<0.05)$.

\begin{tabular}{lcccccccc}
\hline \multirow{2}{*}{ Fragment type } & \multirow{2}{*}{ Area $(\mathrm{ha})$} & \multirow{2}{*}{ Edge $(\mathrm{m})$} & \multicolumn{2}{c}{ Abundance } & \multicolumn{3}{c}{ Diameter $(\mathrm{cm})$} \\
& & & $\mathrm{I}$ & $\mathrm{E}$ & $\mathrm{C}$ & $\mathrm{I}$ & $\mathrm{E}$ & $\mathrm{C}$ \\
\hline $\mathrm{LN}$ & $0.092(0.031)$ & $81.67(6.74)$ & $2.33 \mathrm{c}(1.45) 7$ & $14.67 \mathrm{ab}(2.33) 44$ & $23.0 \mathrm{a} \mathrm{(4.51)} 69$ & $29.49(2.78)$ & $31.58(4.00)$ & $28.47(2.57)$ \\
$\mathrm{NA}$ & $0.075(0.017)$ & $53.30(23.98)$ & $1.75 \mathrm{c}(0.85) 7$ & $12.75 \mathrm{ab}(3.66) 51$ & $5.0 \mathrm{bc}(1.08) 20$ & $25.75(5.12)$ & $28.62(2.13)$ & $21.51(2.68)$ \\
\hline
\end{tabular}

that a given tree was visited by invasive or native ants as the dependent variable.

\section{Results}

3.1. Forest Fragment Traits. Both fragment types (invaded or control) had similar size and shape characteristics (area: $t=0.49, d f=5, P=0.646$; edge: $t=0.88, d f=5, P=$ 0.421 ; edge/area: $t=1.26, d f=5, P=0.264$, Table 1$)$. The interaction between tree category and fragment type was significant (ANOVA, fragment type $\mathrm{x}$ category interaction, $F_{2,15}=5.74, P=0.014$, Table 1$)$. This was due to less abundance of isolated trees in both forest types (Tukey, $P<$ $0.05)$. On the contrary, core trees were significantly more abundant in invaded fragments (Tukey, $P<0.05$ ). However, edge trees did not differ between forest types (Tukey, $P>$ 0.05). Tree diameters were similar for both fragment types, (ANOVA, $F_{2,192}=1.14, P=0.320$ ) and for all categories (ANOVA, $F_{2,192}=0.79, P=0.455$, Table 1$)$. Given the general similarity of those characteristics and the common origin of the forest fragment, we assumed that possible differences in ant foraging in trees in invaded and noninvaded fragments are attributable to the presence of the invader, and not to any environmental gradient.

3.2. Foraging Activity and Richness of Native Ants. Richness of native ants foraging on trees was significantly higher in control than in invaded fragments $(2006, t=-6.35, d f=5$, $P=0.0014$, invaded: $6.67 \pm 0.31$, control: $9.25 \pm 0.27)$ (Table 2). Relative frequencies of native ants diminished markedly in invaded fragments (Table 2).

The spatial foraging of native ants in both fragment types (invaded or control) was the same for all tree categories (repeated measures ANOVA, interaction of forest type $\mathrm{x}$ tree category, $F_{2,13}=2.08, P=0.164$, Figure $2(\mathrm{a})$ ) but in control forest fragments they foraged significantly more than in invaded fragments (repeated measures ANOVA, $F_{1,13}$ $=43.28, P<0.001$, control: $57.63 \pm 3.88 \%$ visited trees, invaded: $13.75 \pm 4.59 \%$ visited trees).

Native ants, in control fragments, remained in all tree categories for a similar time but in invaded fragments they remained significantly more on edge than core trees but some isolated trees were eventually visited (ANOVA, $F_{2,192}=4.06$, $P=0.019$, Tukey $P<0.05$, Figure 2(b)).

Invaded and control forest fragments shared three native ant species whose frequency enabled statistical analysis of their spatial-temporal foraging on trees depending on the fragment type (invaded or control). They are Lasius grandis, Crematogaster scutellaris, and Temnothorax lichtensteini (Table 2).

Spatial tree foraging of Crematogaster scutellaris (Cs) and Temnothorax lichtensteini ( $\mathrm{Tl}$ ) was similar for both forest fragments (repeated ANOVA measures, Cs, $F_{1,13}=0.93$, $P=0.352$; Tl: $\left.F_{1,13}=0.22, P=0.647\right)$. The interactions between fragment type and tree category were not significant (repeated ANOVA measures, Cs, $F_{2,13}=0.41, P=0.672$; Tl: $\left.F_{2,13}=1.04, P=0.382\right)$. In invaded fragments, Lasius grandis appeared in only one fragment, so it was not possible to analyze its spatial tree visitation.

Temporal tree foraging of Crematogaster scutellaris and Temnothorax lichtensteini was similar in both forest fragments (ANOVA, Cs, $F_{1,192}=0.78, P=0.379$; Tl: $F_{1,192}=$ $0.58, P=0.446)$ but the permanence of Lasius grandis differed between fragment types (ANOVA, $F_{1,192}=64.37$, $P<0.001)$. Post hoc comparisons showed that Lasius grandis in control fragments remained for significantly $(P<0.05)$ more months on isolated trees $(2.43 \pm 0.30$ months $)$ than on edge or core trees (edge: $1.22 \pm 0.11$ months, core: $0.65 \pm$ 0.18 months) while in invaded fragments it remained for a similar time $(P>0.05)$ on edge $(1.36 \pm 0.12$ months $)$ and core trees $(0.03 \pm 0.1$ months $)$. There were no isolated trees in the only invaded fragment where Lasius grandis was found.

3.3. Foraging Activity of L. neglectus and Its Effect on Native Ants. In both years, the invasive ant Lasius neglectus (LN) visited significantly more trees than native ants (NA) (repeated ANOVA measures, mean \pm SE, year 2005, LN: $35.67 \pm 3.11 \%$ visited trees, NA: $7.71 \pm 3.11 \%$ visited trees; year 2006, LN: $29.21 \pm 3.87 \%$ visited trees, NA: $13.75 \pm$ $3.87 \%$ visited trees, Table 3 ). The interaction between ant type and tree category (isolated, edge, or core trees) was significant in both years (Table 3 ). Post hoc comparisons showed that in both years the invasive ant foraged significantly more on isolated trees than core trees (Tukey, $P<$ $0.05)$ but edge tree visitation did not differ significantly from the other two categories (Tukey, $P>0.05$, year 2005, isolated trees: $54.36 \pm 6.10 \%$, edge trees: $33.75 \pm 4.98 \%$, core trees: $18.91 \pm 4.98 \%$; year 2006, Figure 3(a)). Native ants in 2005 only visited edge $(13.26 \pm 4.98 \%)$ and core trees $(9.86 \pm$ $4.98 \%, P>0.05)$ while in 2006 all tree categories were visited in similar percentages (Figure 3(a)).

In both years, Lasius neglectus remained on a given tree for significantly more months (year 2005: $2.78 \pm 0.19$ months; 2006: $2.15 \pm 0.16$ months) compared with native ants (year 2005: $0.60 \pm 0.19$ months; 2006: $0.98 \pm 0.16$ 
TABLE 2: Relative frequency (absolute frequency/number of observations) of tree visitation by each ant species at invaded (I) or control (C) forest during the activity period ( 7 months; in 2006). In brackets are shown absolute frequency that is the number of times each ant species was found along the seven censuses (number of observations: 840 at invaded fragments, 546 at control fragments). Ants were discriminated according to their nesting site: soil (S), arboricolous (A), or arboricolous-under bark (U).

\begin{tabular}{lccc}
\hline Ant specie & $\mathrm{I}$ & $\mathrm{C}$ & \\
\hline Lasius neglectus & $0.173(145)$ & & Nesting site \\
Lasius grandis & $0.021(18)$ & $0.176(96)$ & $\mathrm{S}$ \\
Lasius emarginatus & $0.001(1)$ & $0.101(55)$ & $\mathrm{S}$ \\
Crematogaster scutellaris & $0.095(84)$ & $0.148(80)$ & $\mathrm{S}$ \\
Camponotus aethiops & & $0.064(35)$ & $\mathrm{A}$ \\
Camponotus cruentatus & $0.008(7)$ & $0.035(19)$ & $\mathrm{S}$ \\
Camponotus piceus & & $0.002(1)$ & $\mathrm{S}$ \\
Camponotus truncatus & $0.005(4)$ & $0.060(33)$ & $\mathrm{S}$ \\
Formica rufibarbis & & $0.002(1)$ & $\mathrm{A}$ \\
Myrmica spinosior & & $0.015(8)$ & $\mathrm{S}$ \\
Pheidole pallidula & $0.001(1)$ & $0.002(1)$ & $\mathrm{S}$ \\
Plagiolepis pygmaea & $0.004(3)$ & $0.031(17)$ & $\mathrm{S}$ \\
Temnothorax lichtensteini & $0.026(22)$ & $0.038(21)$ & $\mathrm{S}$ \\
Native ant species richness & 8 & 12 & $\mathrm{U}$ \\
\hline
\end{tabular}

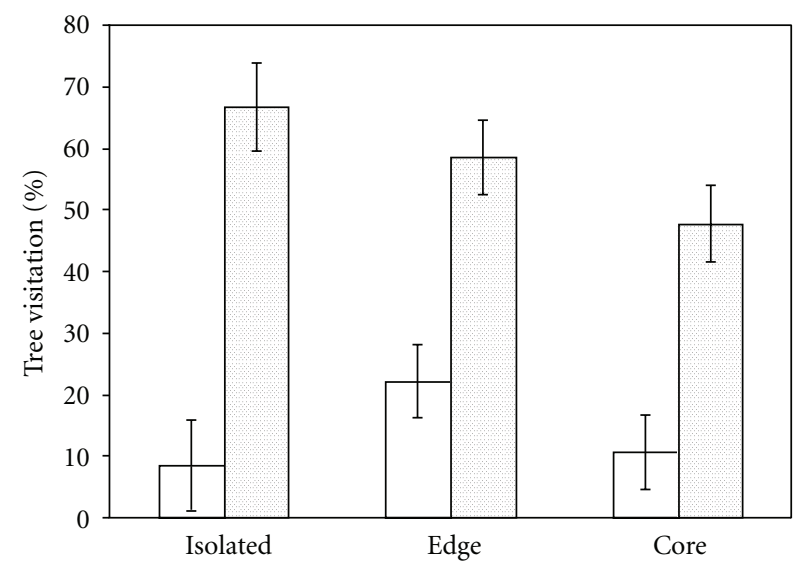

(a)

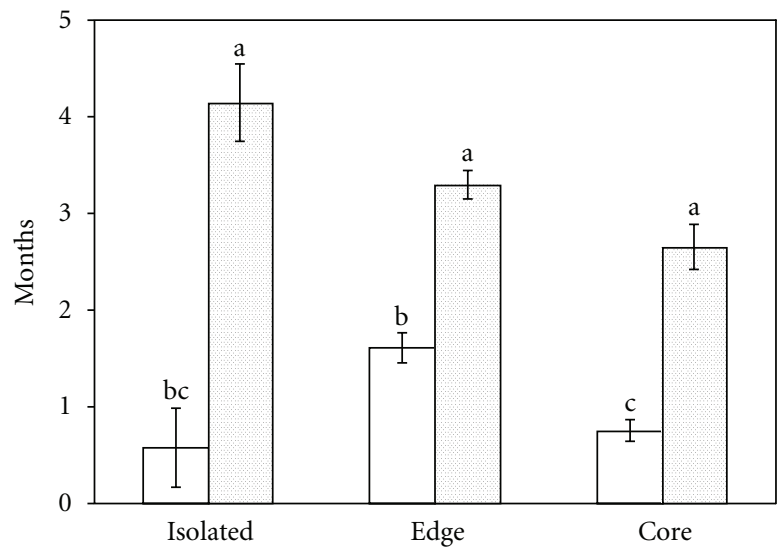

(b)

FIGURE 2: Foraging activity of native ants on trees is shown as the percentage (mean \pm SE) of visited trees (a) and the months they remain visited (b) per tree category in 2006 at invaded fragments (bars in white) or at control fragments (dotted bars). Different letters showed statistical differences of the tree category $\mathrm{x}$ ant type interaction $(P<0.05)$.

months, ANOVA, year 2005: $F_{1,232}=66.29, P<0.001$; year 2006: $\left.F_{1,234}=20.67, P<0.001\right)$. The interaction between ant type and tree category was significant in both years (ANOVA, year 2005: $F_{2,232}=15.27, P<0.001$; year 2006: $F_{2,234}=$ $15.45, P<0.001)$. In both years, the invasive ant remained on isolated trees for significantly more months (year 2005: $4.67 \pm 0.50$ months) in comparison to the permanence on the other two tree categories $(P<0.05$, year 2006, Figure 3(b)). The permanence on edge or core trees of the invasive ant differed significantly $(P<0.05)$ only in 2005 (year 2005, edge: $2.41 \pm 0.19$ months, core: $1.26 \pm 0.15$ months; year 2006, Figure 3(b)). Native ants in 2005, a year in which they did not visit isolated trees, remained for the same time on edge $(1.02 \pm 0.19$ months $)$ and core trees $(0.77 \pm 0.15$ months, $P>0.05)$, whereas in 2006 the permanence of native ants was higher on edge trees $(P<0.05$, Figure $3(b))$.

\section{Discussion}

The consequences of ant invasions on native ant biodiversity has been widely explored. The invasive Argentine ant, Linepithema humile, has competitively displaced native ant species as it has spread in its introduced range [28, 29]. Similarly, the red imported fire ant, Solenopsis invicta, devastated native fauna as it expanded its range across the southeastern United States [30]. In monsoonal Australia, high abundance of the big-headed ant, Pheidole megacephala, corresponded with a $42-85 \%$ decrease in the abundance 
TABLE 3: Repeated measures ANOVA of tree visitation (\%) at invaded fragments, depending on ant type (invasive or native) and tree category (isolated, edge or core trees). Significant effects $(P<0.05)$ are shown in bold.

\begin{tabular}{lcccccc}
\hline & \multicolumn{2}{c}{2005} & & \multicolumn{2}{c}{2006} \\
\hline Source effect & $d f$ & $F$ & $P$ & $d f$ & $F$ & 7.43 \\
Ant type & 1 & 36.72 & $<\mathbf{0 . 0 0 0 1}$ & 1 & $\mathbf{0 . 0 2 1}$ \\
Tree category & 2 & 1.17 & 0.349 & 2 & 0.108 \\
Ant type x Tree category & 2 & 9.67 & $\mathbf{0 . 0 0 5}$ & 2 & $\mathbf{0 . 0 1 0}$ \\
\hline
\end{tabular}

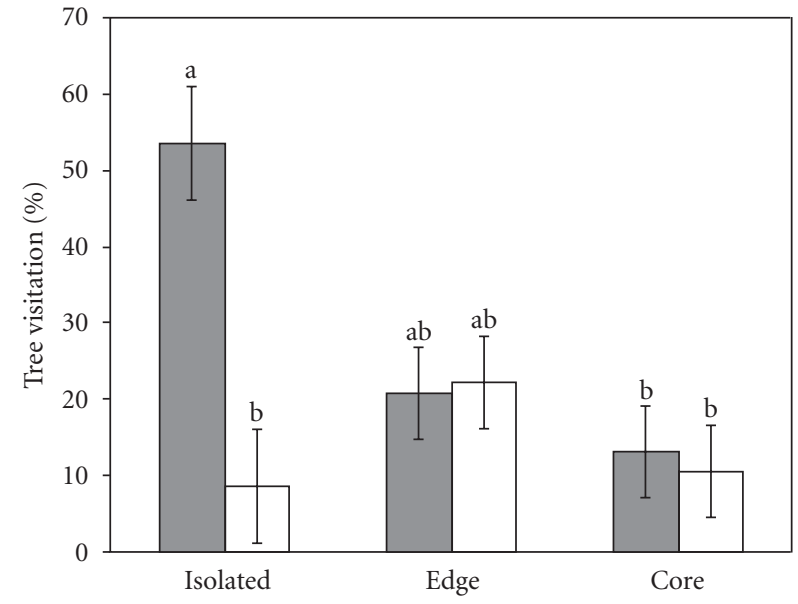

(a)

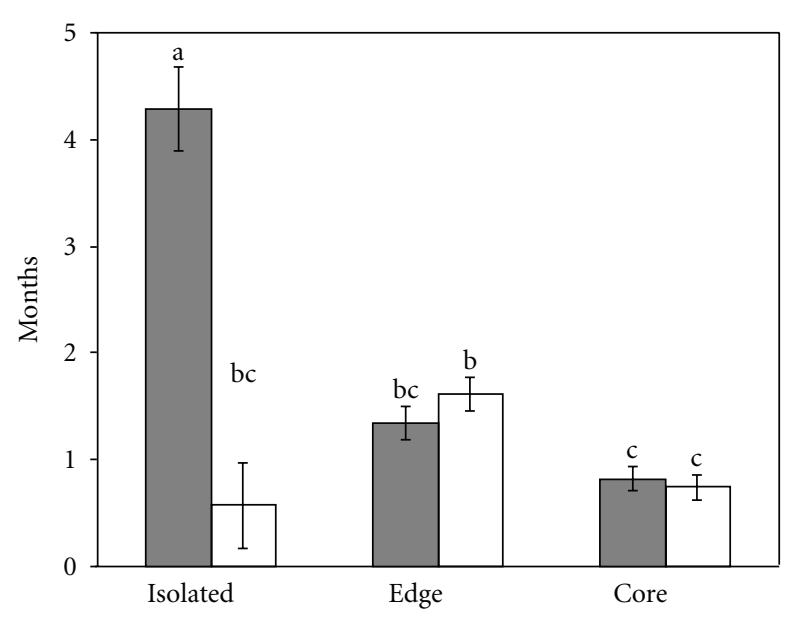

(b)

FIGURE 3: Foraging activity at invaded forest fragments is shown as the percentage (mean \pm SE) of visited trees (a) and the months they remain visited (b) per tree category in 2006. Bars showing trees visited by Lasius neglectus are in grey and visited by native ants are shown in white. Different letters showed statistical differences of post hoc comparisons (tree category $\mathrm{x}$ ant type effect) $(P<0.05)$.

of other native invertebrates [31], and the yellow crazy ant, Anoplolepis gracilipes, displaced other ant species as its activity increased and boundaries expanded on Christmas Island [32]. According to Andersen [33], only those native ant species with specialist foraging times or microhabitat preferences are the most resistant to elimination.

4.1. Foraging Activity and Richness of Native Ants. In our study site, the richness of ants foraging in trees in invaded forest fragments was significantly lower in comparison with control forest fragments. The strongest effect of the presence of L. neglectus is for the congeneric L. grandis and the weakest effect is for smaller and cryptic species. This general finding was already reported by Ward [34] in an Argentine ant invasion in natural habitats of the lower Sacramento River Valley. This effect of L. neglectus on the ant community has been reported by other authors at sites with a higher density of this invasive ant $[18,35]$. The native ants Lasius grandis, Crematogaster scutellaris, and Temnothorax lichtensteini, were encountered in both fragment types (control or invaded) (Table 3) but showed a lower frequency in invaded fragments. All these native species collect honeydew and small insects. In the invaded fragments, the few trees on which Crematogaster scutellaris and Temnothorax lichtensteini were able to forage were visited with the same spatial-temporal tree visitation as in the control fragments. Lasius grandis was found in only one invaded fragment so comparison was not possible with the situation in control fragments where it remained for more months on isolated trees at the highest tree visitation frequency. This could be the consequence of its nesting habit. The native ant Lasius grandis is able to nest in open areas that are associated with isolated trees and dig burrows at the base of visited trees from where workers climb to tend aphids (Paris pers. observ.). The other two native ant species that appeared in all fragments, Crematogaster scutellaris and Temnothorax lichtensteini, have their own ecological particularities that may enable them to coexist with $L$. neglectus. In mixed forests, Crematogaster scutellaris is considered a dominant ant species or codominant with Pheidolle pallidula [36, 37]. This native ant is an arboricolous polydomous nesting ant that changes its nesting location frequently and is highly aggressive. These traits may enable Crematogaster scutellaris to coexist with Lasius neglectus in invaded fragments. Marlier et al. [36] observed, in a fig plantation (Ficus carica L.) with the presence of Lasius neglectus, that the presence of Crematogaster scutellaris did not influence invasive ant activity. Instead, the opposite effect is probably certain although this should be specifically tested. The frequency of tree visitation suggests that in invaded forest fragments Lasius neglectus negatively affected the presence of Crematogaster scutellaris. In fact, in Doñana National Park, Crematogaster scutellaris colonies were successfully displaced from cork oak trees by another invasive ant: Linepithema humile [37]. The other native ant species found in all invaded fragments, Temnothorax lichtensteini, is a cryptic 
species that nests under bark and its small size and low abundance likely diminished the probability of encountering Lasius neglectus. Other authors have also reported that some native ant species are able to coexist with invasive ants. On Christmas Island, Paratrechina minutula and Paratrechina longicornis were commonly found in the same area as the invasive ant Anoplolepis gracilipes supercolony [32]. In Japanese urban parks, Paratrechina sakurae and Camponotus vitiosus coexisted with the invasive ant Linepithema humile [38].

Although our monthly surveys were conducted between 9 and $13 \mathrm{PM}$, we do not expect the situation for native species found in invaded fragments to change over the course of the day because of their foraging patterns. Previous data on Lasius neglectus activity showed that this invasive ant has a $24 \mathrm{hr}$ activity cycle (http://www.creaf.uab.es/ xeg/Lasius/Ingles/gr2dailyactivity.htm). Concerning Lasius grandis, we do not have a detailed $24 \mathrm{hr}$ activity cycle and no information was found in the literature. But a survey performed in the invaded fragments at 6 hour intervals in previous years showed that $L$. grandis was active all day. In fact, other Lasius (s.str.) ant species also showed a $24 \mathrm{hr}$ activity period. Lasius lasioides in northern Tuscany, Italy (Figure 1 [39]), showed continuous activity between May and July. In Maryland, USA Lasius alienus in a woodlot of a second-growth forest composed mostly of oaks (Quercus spp.), and Virginia pines (Pinus virginianus) also showed an activity period of $24 \mathrm{hrs}$ (Figure 3 [40]). According to Redolfi et al. [41], the maximum foraging pattern of Crematogaster scutellaris occurs mainly between 9AM and 16 PM. Concerning T. lichtensteini, which is one of the most abundant ant species in Catalonian forests [42], we found no information about its daily foraging pattern. However, considering that this ant species nests under the bark, that its nest comprises less than 200 individuals, and also that is a timid ant species that forages alone and avoids competition, its presence was probably not perceived by L. neglectus.

Some field observations lead us to speculate on how Lasius neglectus may displace native ants. First, the abundance of Lasius neglectus in trees and soil is higher compared with native ants [35]. This higher abundance increases the possibility of finding and monopolizing food resources to the detriment of native ants [12]. Second, on tree trunk trails, when Lasius neglectus workers find a native ant worker, they try to capture it or show highly aggressive behavior towards it by pulling their legs or antennae. This behavior should disrupt native ant foraging on the canopy, diminishing the food supply for native colonies. The aggressive behavior of Lasius neglectus towards native ants has recently been observed in laboratory aggression tests with Lasius neglectus and other Lasius native ants: attacks by Lasius neglectus were performed faster and most frequently against Lasius grandis, were intermediate against Lasius emarginatus, and delayed in time and less frequent against Lasius cinereus [43]. Finally, recently fertilized native queens of Messor sp and Lasius grandis that landed on invaded forest fragments were captured immediately by Lasius neglectus workers (Paris pers. observ.). Hence, the invasive ant may directly interfere with the establishment of new native colonies.
4.2. Foraging Activity of L. neglectus and Its Effect on Native Ants. In both years, spatial-temporal tree visitation by the invasive ant Lasius neglectus was higher than that of the native ants found in invaded fragments. In particular, isolated trees were more visited and for a longer time by the invasive ant in comparison with other tree categories and with native ant foraging on trees. The polydomous colony structure of L. neglectus enables them to move freely among trees with a higher aphid abundance. On the contrary, the native ants may deal with territorial constraints that inhibit them from foraging for a long time on trees previously occupied by other native ants. The Argentine ant Linepithema humile is also prone to relocate its nest close to food sources on trees and move away when sources are exhausted or workers do not have access to climb the tree [44]. This strategy enables invasive ants to monopolize honeydew sources in order to maintain the large worker activity for community dominance. On the other hand, the fragmentation of the forest also plays an important role in modifying, at the edges, the availability of honeydew sources, the environment, and the ant community. These factors may interact to favor the foraging of L. neglectus and some native ants in the case of control fragments. In fact, several studies have recorded increased abundance of tended phytophagous insects such as aphids and treehoppers, on isolated and edge trees from patches of scrubland, neotropical savanna and tropical and temperate forest fragments [45-47]. This edge effect appears to be the result of the interaction between two adjacent ecosystems when they are separated by an abrupt limit [48]. The response may differ depending on the group. In rainforests, some insect groups respond positively to edges while others are negatively affected. Certain termites, leafhoppers, scale insects, aphids, aphid-tending ants [46], and light-loving butterflies [49] increase near edges. In particular, ant-tended aphids increase on isolated trees [47]. On the contrary, numerous bees, wasps [46], ants and butterflies [49] respond negatively to edges. Additionally, at forest edges, ant richness diminishes, ant community composition is modified [50, 51], and a variety of ecosystem processes [52], such as seed dispersion by ants, may change [53]. In a previous study in the same area, we found no differences in aphid abundance tended by $L$. neglectus or the native ant $L$. grandis on holm oaks located at the edge and isolated [19]. However, not all trees were surveyed due to their height and the slope of the area. Therefore, we cannot discount the possibility of there being a gradient in the abundance of tended-aphids from the core of the forest fragment to the edges.

\section{Conclusions}

In invaded fragments, spatial-temporal foraging of native ants and their richness on trees was strongly diminished in comparison with control fragments. However, the native ants Crematogaster scutellaris and Temnothorax lichtensteini, both arboricolous, were able to coexist with the invasive ant but showed a lower frequency of foraging on trees and remained for less time in comparison with their permanence in control fragments. The mechanisms that may enable coexistence 
between native and L. neglectus were a combination of small body size, arboreal nesting habits, and cryptic behavior. Additional sampling approaches (pitfall trap captures, presence in baits, leaf litter sampling) are needed to ascertain the generality of those mechanisms. Some uncoupling of ground foraging and tree foraging levels has been detected in Argentine ants [54].

Forest fragments with high edge-to-interior ratios or disturbance-induced edges are highly susceptible to ant invasion, which can reach natural areas using roads and forest edges as dispersion paths $[14,25,26]$. Isolated trees are usually found on paths and roadsides and have been proposed as spreading corridors for Lasius neglectus [55]. In fact, isolated trees were visited more and for a longer time by Lasius neglectus than by native ants. Preventing the abundance of aphids on isolated trees or making it difficult for ants to climb trunks should help prevent this invasive ant from reaching other sites. Additionally, monitoring of road edges that pass through an invaded area will help with the early detection of new propagules of L. neglectus.

\section{Acknowledgments}

The comments of two reviewers added value to the manuscript and pointed to relevant literature. C. Paris would like to thank the Government of Catalonia for the grant for young researchers (2003FI 00342) and to Elizabeth Padilla for helping in field work. Funding was provided by MEC/ FEDER CGL 2004-05240-CO2/01 and CGL2007-64080C02-01.

\section{References}

[1] C. R. Carroll and D. H. Janzen, "The ecology of foraging ants," Annual Review of Ecology and Systematics, vol. 4, pp. 231-257, 1973.

[2] X. Cerdá, J. Retana, and A. Manzaneda, "The role of competition by dominants and temperature in the foraging of subordinate species in Mediterranean ant communities," Oecologia, vol. 117, no. 3, pp. 404-412, 1998.

[3] H. Gibb, "The effect of a dominant ant, Iridomyrmex purpureus, on resource use by ant assemblages depends on microhabitat and resource type," Austral Ecology, vol. 30, no. 8, pp. 856-867, 2005.

[4] A. Wielgoss, T. Tscharntke, D. Buchori, B. Fiala, and Y. Clough, "Temperature and a dominant dolichoderine ant species affect ant diversity in Indonesian cacao plantations," Agriculture, Ecosystems and Environment, vol. 135, no. 4, pp. 253-259, 2010.

[5] B. Hölldobler and E. O. Wilson, The Ants, Harvard University Press, Cambridge, Mass, USA, 1990.

[6] D. T. Briese and B. J. Macauley, "Temporal structure of an ant community in semi-arid Australia," Australian Journal of Ecology, vol. 5, pp. 121-134, 1980.

[7] X. Cerdá, J. Retana, and S. Cros, "Thermal disruption of transitive hierarchies in Mediterranean ant communities," Journal of Animal Ecology, vol. 66, no. 3, pp. 363-374, 1997.

[8] M. N. Sheata and A. H. Kaschef, "Foraging activities of Messor aegyptiacus emery (Hym., Formicidae)," Insectes Sociaux, vol. 18 , no. 4, pp. 215-226, 1971.
[9] T. Lewis, G. V. Pollard, and G. C. Dibley, "Micro-environmental factors affecting diel patterns of foraging in the leafcutting ant Atta cephalotes(L.) (Formicidae: Attini)," The Journal of Animal Ecology, vol. 43, pp. 143-153, 1974.

[10] A. C. Mailleux, J. L. Deneubourg, and C. Detrain, "Regulation of ants' foraging to resource productivity," Proceedings of the Royal Society B, vol. 270, no. 1524, pp. 1609-1616, 2003.

[11] S. Portha, J. L. Deneubourg, and C. Detrain, "Self-organized asymmetries in ant foraging: a functional response to food type and colony needs," Behavioral Ecology, vol. 13, no. 6, pp. 776-781, 2002.

[12] D. W. Davidson, "Resource discovery versus resource domination in ants: a functional mechanism for breaking the tradeoff," Ecological Entomology, vol. 23, no. 4, pp. 484-490, 1998.

[13] A. N. Andersen, "Regulation of "momentary" diversity by dominant species in exceptionally rich ant communities of the Australian seasonal tropics," American Naturalist, vol. 140, no. 3, pp. 401-420, 1992.

[14] D. A. Holway, L. Lach, A. V. Suarez, N. D. Tsutsui, and T. J. Case, "The causes and consequences of ant invasions," Annual Review of Ecology and Systematics, vol. 33, pp. 181-233, 2002.

[15] J. D. Styrsky and M. D. Eubanks, "Ecological consequences of interactions between ants and honeydew-producing insects.," Proceedings Biological Sciences/The Royal Society, vol. 274, no. 1607, pp. 151-164, 2007.

[16] A. J. Van Loon, J. J. Boomsma, and A. Andrasfalvy, "A new polygynous Lasius species (Hymenoptera; Formicidae) from central Europe-I. Description et biologie générale-I. Description and general biology," Insectes Sociaux, vol. 37, no. 4, pp. 348-362, 1990.

[17] N. D. Tsutsui and A. V. Suarez, "The colony structure and population biology of invasive ants," Conservation Biology, vol. 17, no. 1, pp. 48-58, 2003.

[18] X. Espadaler, A. Tartally, R. Schultz, B. Seifert, and C. Nagy, "Regional trends and preliminary results on the local expansion rate in the invasive garden ant, Lasius neglectus (Hymenoptera, Formicidae)," Insectes Sociaux, vol. 54, no. 3, pp. $293-$ $301,2007$.

[19] C. I. Paris and X. Espadaler, "Honeydew collection by the invasive garden ant Lasius neglectus versus the native ant $L$. grandis," Arthropod-Plant Interactions, vol. 3, no. 2, pp. 75-85, 2009.

[20] C. Nagy, A. Tartally, F. Vilisics et al., "Effects of the invasive garden ant, Lasius neglectus Van Loon, Boomsma \& AndráS-Falvy, 1990 (Hymenoptera: Formicidae), On arthropod assemblages: Pattern analyses in the type supercolony," Myrmecological News, vol. 12, pp. 171-181, 2009.

[21] X. Espadaler, S. Rey, and V. Bernal, "Queen number in a supercolony of the invasive garden ant, Lasius neglectus," Insectes Sociaux, vol. 51, no. 3, pp. 232-238, 2004.

[22] S. Rey and X. Espadaler, "Area-wide management of the invasive garden ant Lasius neglectus (Hymenoptera: Formicidae) in Northeast Spain," Journal of Agricultural and Urban Entomology, vol. 21, no. 2, pp. 99-112, 2004.

[23] E. Groden, F. A. Drummond, J. Garnas, and A. Franceour, "Distribution of an invasive ant, Myrmica rubra (Hymenoptera: Formicidae), in Maine," Journal of Economic Entomo$\log y$, vol. 98, no. 6, pp. 1774-1784, 2005.

[24] J. D. Majer, J. H. C. Delabie, and N. L. McKenzie, "Ant litter fauna of forest, forest edges and adjacent grassland in the Atlantic rain forest region of Bahia, Brazil," Insectes Sociaux, vol. 44, no. 3, pp. 255-266, 1997.

[25] A. V. Suarez, D. T. Bolger, and T. J. Case, "Effects of fragmentation and invasion on native ant communities in coastal 
southern California," Ecology, vol. 79, no. 6, pp. 2041-2056, 1998.

[26] D. Colomer, R. Corretger, A. Florensa, and P. Martí, Diagnosi Ambiental del Campus de la Universitat Autònoma de Barcelona, Document de memòria. A21 campus. Universitat Autònoma de Barcelona, 2000.

[27] StatSoft, "STATISTICA (data analysis software system), version 6," http://www.statsoft.com/.

[28] K. G. Human and D. M. Gordon, "Exploitation and interference competition between the invasive Argentine ant, Linepithema humile, and native ant species," Oecologia, vol. 105, no. 3, pp. 405-412, 1996.

[29] D. A. Holwa, "Factors governing rate of invasion: a natural experiment using Argentine ants," Oecologia, vol. 115, no. 12, pp. 206-212, 1998.

[30] C. R. Allen, S. Demarais, and R. S. Lutz, "Red imported fire ant impact on wildlife: an overview," Texas Journal of Science, vol. 46, no. 1, pp. 51-59, 1994.

[31] B. D. Hoffmann, A. N. Andersen, and G. J. E. Hill, "Impact of an introduced ant on native rain forest invertebrates: Pheidole megacephala in monsoonal Australia," Oecologia, vol. 120, no. 4, pp. 595-604, 1999.

[32] K. L. Abbott, "Spatial dynamics of supercolonies of the invasive yellow crazy ant, Anoplolepis gracilipes, on Christmas Island, Indian Ocean," Diversity and Distributions, vol. 12, no. 1, pp. 101-110, 2006.

[33] A. N. Andersen, "Not enough niches: non-equilibrial processes promoting species coexistence in diverse ant communities," Austral Ecology, vol. 33, no. 2, pp. 211-220, 2008.

[34] P. S. Ward, "Distribution of the introduced Argentine ant (Iridomyrmex humilis) in natural habitats of the lower Sacramento Valley and its effects on the indigenous ant fauna," Hilgardia, vol. 55, no. 2, pp. 1-16, 1987.

[35] S. Rey, Biologia, ecologia i efectes de la formiga Lasius neglectus (Hymenoptera, Formicidae) en comunitats d'artròpodes [Ph.D. thesis], Universitat Autònoma de Barcelona, 2007.

[36] J. F. Marlier, B. Schatz, and J. C. de Biseau, "Influence de Crematogaster scutellaris (Hymenoptera: Myrmicinae) sur deux communautés de fourmis," Actes des Colloques Insectec Sociaux, vol. 15, pp. 68-72, 2002.

[37] S. Carpintero, J. Reyes-López, and L. A. De Reyna, "Impact of Argentine ants (Linepithema humile) on an arboreal ant community in Doñana National Park, Spain," Biodiversity and Conservation, vol. 14, no. 1, pp. 151-163, 2005.

[38] Y. Touyama, K. Ogata, and T. Sugiyama, "The Argentine ant, Linepithema humile, in Japan: assessment of impact on species diversity of ant communities in urban environments," Entomological Science, vol. 6, pp. 57-62, 2003.

[39] G. Santini, L. Tucci, L. Ottonetti, and F. Frizzi, "Competition trade-offs in the organisation of a Mediterranean ant assemblage," Ecological Entomology, vol. 32, no. 3, pp. 319-326, 2007.

[40] J. H. Fellers, "Daily and seasonal activity in woodland ants," Oecologia, vol. 78, no. 1, pp. 69-76, 1989.

[41] I. Redolfi, A. Tinaut, F. Pascual, and M. Campos, "Patrón de actividad de Tapinoma nigerrima (Nylander) y Crematogaster scutellaris (Olivier) Hymenoptera, Formicidae) en el cultivo de olivo y en el laboratorio," Zoologica Baetica, vol. 13-14, pp. 37$55,2002-2003$.

[42] X. Espadaler and V. Bernal, "La fauna de formigues de les clapes de bosc," in La Fragmentació dels Boscos de la Plana del Vallès, F. Rodà, Ed., pp. 201-229, Fundació Abertis, 2005.

[43] S. Cremer, L. V. Ugelvig, S. T. E. Lommen, K. S. Petersen, and J. S. Pedersen, "Attack of the invasive garden ant: aggression behaviour of Lasius neglectus (Hymenoptera: Formicidae) against native Lasius species in Spain," Myrmecologiche Nachrichten, vol. 9, pp. 13-19, 2006.

[44] R. J. Brightwell and J. Silverman, "Effects of honeydewproducing hemipteran denial on local argentine ant distribution and boric acid bait performance," Journal of Economic Entomology, vol. 102, no. 3, pp. 1170-1174, 2009.

[45] K. Del-Claro and P. S. Oliveira, "Ant-homoptera interactions in a neotropical savanna: the honeydew-producing treehopper, Guayaquila xiphias (Membracidae), and its associated ant fauna on Didymopanax vinosum (Araliaceae)," Biotropica, vol. 31, no. 1, pp. 135-144, 1999.

[46] H. G. Fowler, C. A. Silva, and V. Ventincinque, "Size, taxonomic and biomass distributions of flying insects in Central Amazonian: forest edge versus understory," Revista de Biología Tropical, vol. 41, pp. 755-760, 1993.

[47] C. M. P. Ozanne, M. R. Speight, C. Hambler, and H. F. Evans, "Isolated trees and forest patches: patterns in canopy arthropod abundance and diversity in Pinus sylvestris (Scots Pine)," Forest Ecology and Management, vol. 137, no. 1-3, pp. 53-63, 2000.

[48] C. Murcia, "Edge effects in fragmented forests: implications for conservation," Trends in Ecology and Evolution, vol. 10, no. 2, pp. 58-62, 1995.

[49] K. S. Brown Jr. and R. W. Hutchings, "Disturbance, fragmentation and the dynamics of diversity in Amazonian forest butterflies," in Tropical Forest Remnants: Ecology, Management and Conservation of Fragmented Communities, W. F. Laurance and R. O. Bierregard Jr., Eds., pp. 91-110, University of Chicago Press, Chicago, Ill, USA, 1997.

[50] K. S. Carvalho and H. L. Vasconcelos, "Forest fragmentation in central Amazonia and its effects on litter-dwelling ants," Biological Conservation, vol. 91, no. 2-3, pp. 151-157, 1999.

[51] T. G. Sobrinho and J. H. Schoereder, "Edge and shape effects on ant (Hymenoptera: Formicidae) species richness and composition in forest fragments," Biodiversity and Conservation, vol. 16, no. 5, pp. 1459-1470, 2007.

[52] W. F. Laurance, T. E. Lovejoy, H. L. Vasconcelos et al., "Ecosystem decay of Amazonian forest fragments: a 22-year investigation," Conservation Biology, vol. 16, no. 3, pp. 605-618, 2002.

[53] J. H. Ness, "Forest edges and fire ants alter the seed shadow of an ant-dispersed plant," Oecologia, vol. 138, no. 3, pp. 448454, 2004.

[54] C. D. Grover, K. C. Dayton, S. B. Menke, and D. A. Holway, "Effects of aphids on foliar foraging by Argentine ants and the resulting effects on other arthropods," Ecological Entomology, vol. 33, no. 1, pp. 101-106, 2008.

[55] A. Tartally, "Long term expansion of a supercolony of the invasive garden ant, Lasius neglectus (Hymenoptera: Formicidae)," Myrmecologiche Nachrichten, vol. 9, pp. 21-25, 2006. 

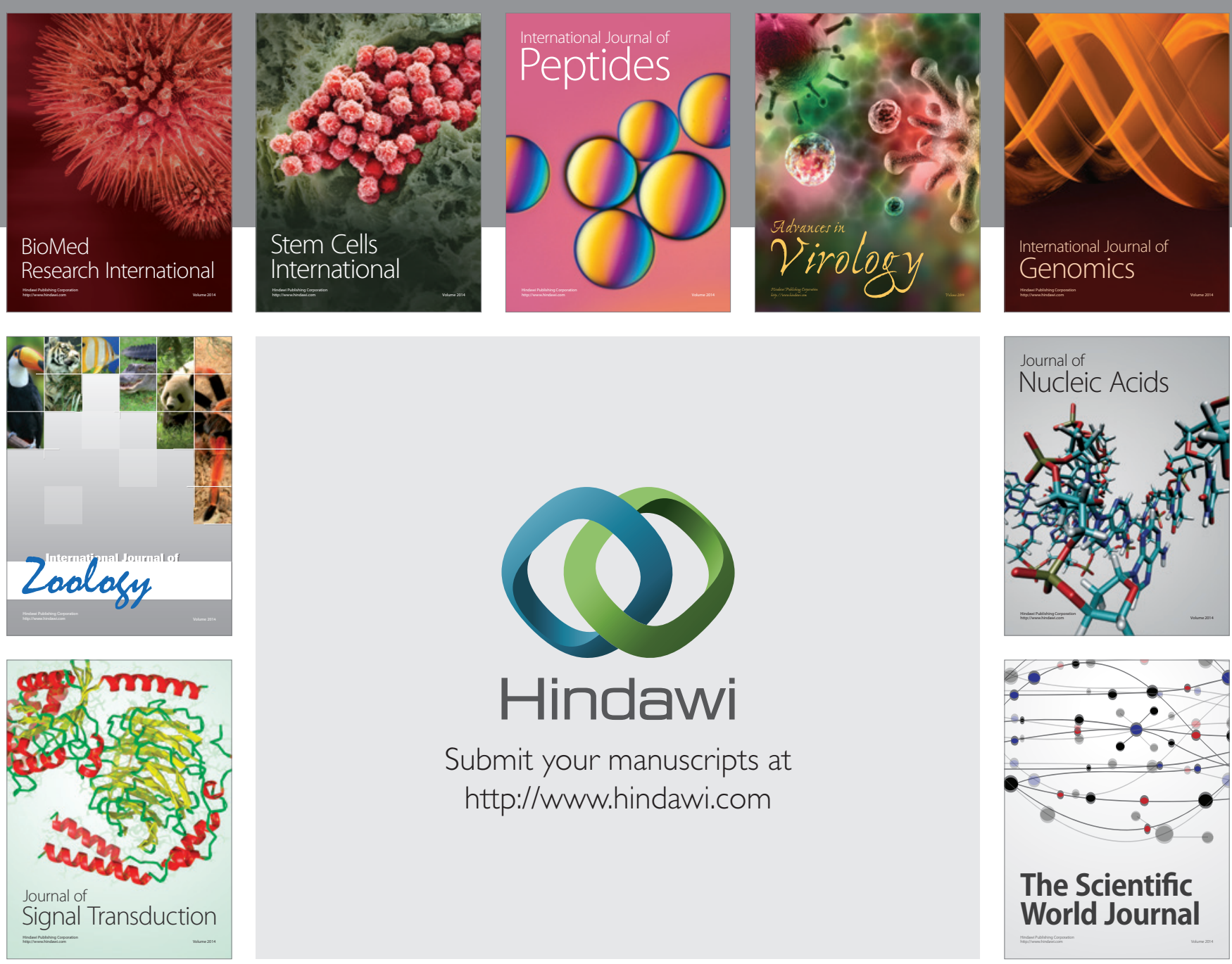

Submit your manuscripts at

http://www.hindawi.com
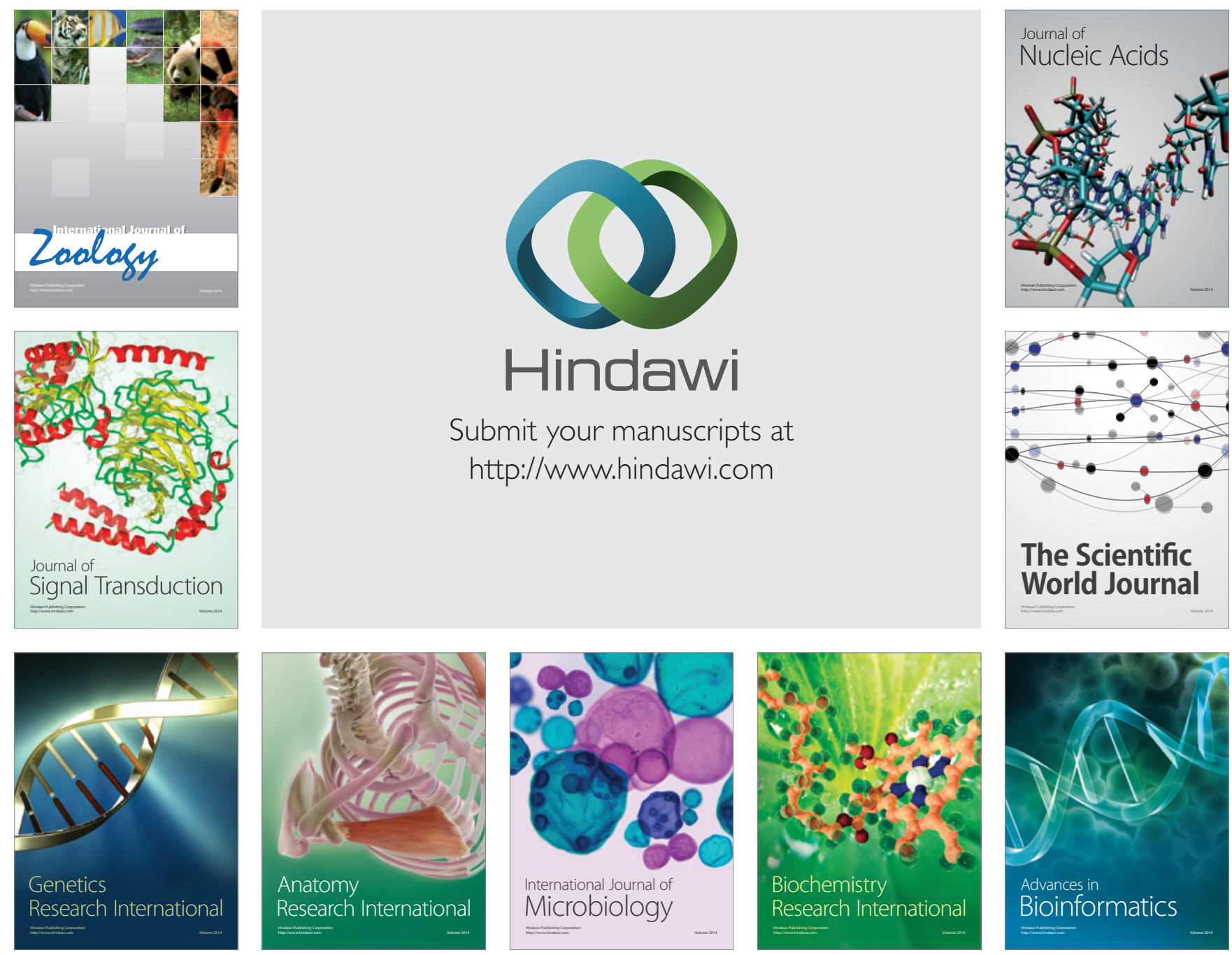

The Scientific World Journal
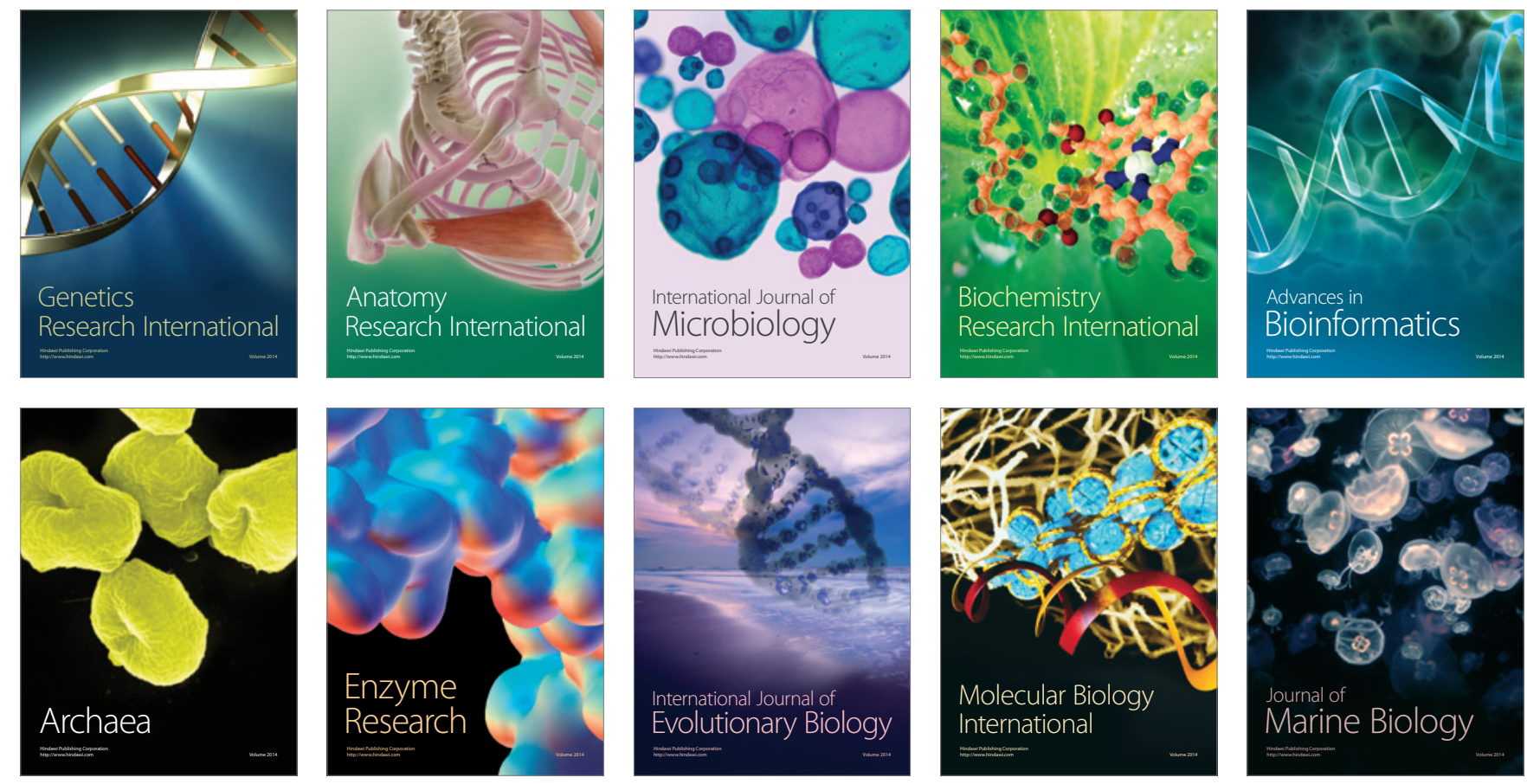